Vol. 1, No. 1 June 2020: p. 61-74. DOI: 10.18326/islah vli1.61-74

Website: https://e-journal.iainsalatiga.ac.id/index.php/islah

\title{
The Application of Narrative Theory by Greimas in Understanding the Story of the Garden Owners in Al Qalam verses 17-32
}

\author{
Muhammad Alwi HS \\ Fakultas Ushuluddin dan Pemikiran Islam / UIN Sunan Kalijaga \\ muhalwihs 2 gmail.com
}

\section{Iin Parninsih}

Fakultas Ushuluddin / UIN Syarif Hidayatullah Jakarta

iin.parninsihgmail.com

\begin{abstract}
This paper discussed semiotics in conveying the story in the Qur'an focusing on the application of narrative theory from A.J. Greimas in the story about Owners of the Garden in surah al-Qalam verses 17-32. This study was carried out because there were only a few researches on this story, including from the perspective of semiotics that have not been done before though this story contains moral values that need to be disclosed. Therefore, assuming that through this story, al Qur'an has an ideal moral mission for people, especially the Muslims either they understand it by themselves or using other discipline like semiotics. This study showed the importance of discussing the story in al-Qur'an by integrating Islamic knowledge and the knowledge from other disciplines, namely semiotics. This research was aimed at describing how to understand the narrative and moral ideal in the story about Owners of the Garden in surah al-Qalam: 17-32 based on A.J.'s narrative theory by Greimas. Keywords: Story about Owners of the Gardens, surah al-Qalam, Narrative, A.J. Greimas
\end{abstract}

\begin{abstract}
Abstrak
Tulisan ini hendak mendiskusikan pembacaan semiotika dalam mengungkap pemahaman atas kisah dalam al-Qur'an, yang dalam hal ini akan berfokus pada penerapan teori naratif dari A.J. Greimas atas kisah pemilik kebun dalam surah al-Qalam ayat 17-32. Pengambilan kisah pemilik kebun disebabkan masih sangat minimnya penelitian yang membahas kisah tersebut, termasuk pembacaan semiotika yang belum dilakukan. Padahal dalam kisah tersebut mengandung nilai moral yang perlu diungkapkan. Karena itu, berangkat dari asumsi bahwa al-Qur'an melalui kisah pemilik kebun memiliki misi ideal moral untuk umat manusia -khususnya umat Islam, baik pemahaman dalam dirinya sendiri maupun berangkat dari keilmuan dari luar, maka tulisan ini akan membuktikan nilai penting kehadiran kisah dalam al-Qur'an melalui integrasi keilmuan di luar islam, yakni semiotika. Adapun rumusan masalah yang hendak dijawab dalam tulisan ini adalah bagaimana pemahaman narasi dan ideal moral dalam kisah pemilik kebun pada QS. Al-Qalam: 17-32 berdasarkan teori naratif A.J. Greimas?
\end{abstract}

Kata Kunci: Kisah Pemilik Kebun, QS. al-Qalam, Naratif, A.J. Greimas. 
The Application of Narrative Theory by Greimas...(Muhammad Alwi HS \& Iin Parninsih)

\section{INTRODUCTION}

Qur'an, as a book of guidance to human life especially to all Muslims (QS. Al-Baqarah: 02 and 185), always attracts people to study about it. There are many studies which are based on this holy Qur'an that continue to occur throughout the age, therefore it is known as shalihun li kulli zaman wa makan. Husein Aziz, for example, concluded that one of the miracles of the Qur'an is that it is always superior and reaches newness even in the modern era. ${ }^{1}$ This paper will discuss the miracles of Qur' an in terms of the story contained in it. The story in the Qur'an always has important values for Muslims. ${ }^{2}$

These stories are then integrated with the semiotic discourse, as a scientific field from outside Islamic knowledge. Semiotics is a scientific discipline that has a significant influence, either as a method of study (decoding) or as a method of creation (encoding). ${ }^{3}$ Some semiotics experts, as revealed by Yasraf Amir such as Umberto Eco, Roland Barthes, Coward and Ellis are agreed that the discussion of semiotics is not limited by who gives the sign, whether human, animal, or even God. Therefore, as long as it is a sign used in a sign and a communication system and agreed between the sender and the recipient, it is included in the study of semiotics, while in this case it is the signs or the Religious sciences ${ }^{4}$. Furthermore, according to Ahmad Muzakki, al-Qur'an which became a study of semiotics is the word of God that is already compiled in a written text (mushaf), not before it was written, ${ }^{5}$ including the stories in it.

Actually, there are a lot of studies that discuss the stories in the Qur'an, both in the form of story compilation or focusing on one specific story such as, Qishashul al-Qur'an

${ }^{1}$ Husein Aziz. 2017. Kontekstualisasi Kemukjizatan Sastrawi al-Qur'an, Islamica Vol 11 (2) page. 418.

${ }^{2}$ M. Quraish Shihab draws some conclusions from the procurement of stories in the Qur'an, that first, the story that has a relationship with humans personally shows the lessons or examples that can be learned from that person. Even if the person is told about the bad side (or weakness), then the Qur'an always draws conclusions that are conscious at the end of the story. Second, the story that presents the situation of the community is an attempt to take lessons from the community, either from the cause of the fall of the community, or anything that makes the society civilized. See more on M. Quraish Shihab. 2013. Kaidah Tafsir: Syarat, ketentuan dan aturan yang patut anda ketahui dalam memahami ayat-ayat al Qur'an. Tangerang

3 Yasraf Amir Piliang. 2003. Hipersemiotika: Tafsir Cultural Studies atas Matinya Makna, Yogyakarta: Jalasuta, page. 255.

${ }^{4}$ Yasraf Amir Piliang. 2003. Semiotika dan Hipersemiotika: Gaya, Kode, dan Matinya Makna. Bandung: Matahari, page 362.

5 Ahmad Muzakki. 2007. Kontribusi Semiotika dalam Memahami Bahasa Agama. Malang: UINMalang Press, 2007, page 101 
(The Book of Stories in al-Qur'an) by Muhammad Ahmad Jadul and other writers. ${ }^{6}$ This book conveys the story of the Garden Owners, which is the focus of the author's study. The book Seri Kisah-kisah dalam al-Qur'an (series $1^{7}$ and $2^{8}$ ) by Bung Smas, Al-Aabaa wal Abnaa fil Qur'anil Karim (The Story of the Father and Son in al-Qur'an) by Adil Musthafa

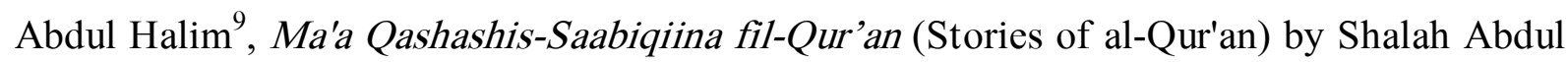
Fattah al-Khalidy ${ }^{10}$ and Kisah-kisah Pembebasan dalam al Qur'an by Eko Prasetyo, ${ }^{11}$ and many more works that reveal stories in the Qur'an.

Furthermore, there are many stories that have been integrated with semiotic studies as well, such as Semiotika al Qur'an: Metode dan Aplikasi terhadap Kisah Yusuf written by Ali Imron ${ }^{12}$, thesis research Kisah Zu Al-Qarnain dalam al Qur'an (Telaah Semiotik) by Nor Faridat unnisa $^{13}$, and other works. Specifically, many studies on semiotics using the narrative theory by A.J. Greimas has also been carried out, such as the study on Aplikasi Semiotika Naratif AJ. Greimas terhadap Kitab Thalut dalam al, Qur'an by Nor Istiqomah. ${ }^{14}$ There are still many other studies reveal the stories in the Qur'an which would not be enough to write them in this paper. The stories in the Qur'an is a treasure or khazanah which attracted people's attention to study about it, and semiotics plays an important role in giving an understanding about it. However, despite many studies mentioned above, there is only one book that contain the story of the Owner of the Garden though it is just a chapter in that book. Therefore, to develop the story, this study will discuss it in the form of a semiotic study using the narrative theory by A.J. Greimas.

\footnotetext{
${ }^{6}$ Muhammad Ahmad Jadul, Muhammad Abu Fadhli Ibrahim, dkk. 2009. Buku Induk Kisah Al-Qur'an, terj. Abdurrahman Assegaf. Jakarta: Zaman.

${ }^{7}$ Bung Smas. 2012. Seri Kisah-kisah dalam al-Qur'an Seri 1. Bandung: Remaja Rosdakarya.

${ }^{8}$ Bung Smas. 2012. Seri Kisah-kisah dalam al-Qur'an Seri 2. Bandung: Remaja Rosdakarya.

9 Adil Musthafa Abdul Halim. 2007. Kisah Bapak dan Anak dalam al-Qur'an, terj. Abdul Hayyie alKatani dan Fitriah Wardie. Jakarta: Gema Insani.

${ }^{10}$ Shalah Abdul Fattah al-Khalidy. 2000. Kisah-kisah al-Qur'an, terj. Setiawan Budi Utomo. Jakarta: Gema Insani.

${ }^{11}$ Eko Prasetyo. 2012. Kisah-kisah pembebasan dalam al-Qur'an. Yogyakarta: Resist Book.

${ }^{12}$ Ali Imron, Semiotika Al-Qur'an: Metode dan Aplikasi terhadap Kisah Yusuf, (Yogyakarta: Teras, 2011). This book is a continuation of the author's thesis research, see more on Ali Imron, "Kisah Nabi Yusuf A.S. dalam al-Qur'an" a thesis at the Faculty of Ushuluddin and Islamic Thought, UIN Sunan Kalijaga.

${ }^{13}$ Nor Faridatunnisa. 2015. Kisah-Kisah Zu al-Qurnain dalam al-Qur'an, a thesis at the Faculty of Ushuluddin and Islamic Thought, UIN Sunan Kalijaga.

${ }^{14}$ Nor Istiqomah. 2017. Aplikasi Semiotika Naratif A.J. Greimas terhadap Kisah Thalut dalam alQur'an. Qof, Volume 1 (2)
} 
The Application of Narrative Theory by Greimas...(Muhammad Alwi HS \& Iin Parninsih)

\section{METHODOLOGY}

This research uses analytical-descriptive method and the data will be analysed based on the theory of A.J. Greimas about narratives. As for the primary data is surah al-Qalam verses 1732, while the secondary data is all available sources (books, journal articles, etc.) that are related to the discussion of this study. This paper has two main objectives, namely first is to prove that the study of semiotics is able to reveal the content of the Qur'an, in this case Greimas's narrative theory. Second, this study aims to convey the understanding of the story about the owner of garden contained in the QS. al-Qalam 17:32.

\section{RESULTS AND DISCUSSION}

\section{A.J. Greimas and the Narrative Theory}

Algirdas Julian Greimas is a great thinker who adheres to structural theory. ${ }^{15}$ He was born in Russia, precisely in the Tula region on March 9, 1917. He graduated with a major in law at the University of Grenoble in 1939. After that, he returned to his hometown, Lithuania, to teach and work as an editor and write various articles about literature and cultural criticism around 1940. Four years later (1944), he returned to France to continue his doctoral studies and wrote a thesis about "Le Mode en 1830: Essay de Descrition du vocabulaire de I'epoque" in 1949. Some his famous works are Structural Semantique (English: Semantic Structural, 1983), Mythology (On Gods and Men in 1979), and In Search of National Memory, and others. Greimas died in 1992. ${ }^{16}$

Greimas developed structural theories into structural narratives, even in his work he formulated the concept of a narrative unit called actants, at the same time, Greimas continued developing the Propp theory. ${ }^{17}$ Actants literally means the actions performed by the living things so that it reveals syntactic units. ${ }^{18}$ Greimas's narrative theory was developed from the basic assumption that the narrative text is composed of structural analogies in linguistic from Saussure on the one hand, and on the other hand sourced from

${ }^{15}$ Fredric Jameson in Algirdas Julien Greimas. 1987. On Meaning Selected Writing in Semiotic Theory, terj. Perron and Frank H. Collins. Canada: University of Minnesota Press, page vi. page $80-81$.

${ }^{16}$ Nor Istiqomah. Aplikasi Semiotika Naratif A.J. Greimas terhadap Kisah Thalut dalam al-Qur'an,

17 Cyntia Dewi Anggraini, dkk, “Analisis Struktural Naratif Algirdas Greimas pada Artikel Storytelling Project Sunlight PT. Unilever Indonesia in November 2014” e-Proceeding of Management, vol. 3 (1) April page 931

${ }^{18}$ A.j. Greimas and J. Courtes. 1982. Semiotika and Language: An Anlytical Dictionary, translated by Larry Crist (Bloomington: Indiana University Press, page 5. 
Propp's theory. Furthermore, Greimas summarizes Propp's concept of 31 functions of action into 20 functions, which are then grouped into three syntagms, namely: Syntagmes Contractuels (based on agreement), Syntagmes Performanciel (organizing), and Syntagmes Disjontionnels (terminating). ${ }^{19}$

Furthermore, Greimas shows two elements of semiotics that are always present. The first element is extrinsic structural element: which is clearly illustrated in the arrangement of words or sentences. The second element is inner structure which is understood from behind the composition of words or sentences. To find the extrinsic structure of a text, the actants will be mapped as follows: ${ }^{20}$

\begin{tabular}{lll}
\hline Kind of actants & $\begin{array}{l}\text { Meaning of } \\
\text { actants }\end{array}$ & \multicolumn{1}{c}{ Explanation } \\
\hline Adressant/Sender & $\begin{array}{l}\text { Booster/ } \\
\text { Stories } \\
\text { Recipient }\end{array}$ & $\begin{array}{l}\text { Reference that reveals to the rules and values and } \\
\text { ideology of the text } \\
\text { The one who bring the value of the destinator / } \\
\text { object whe he put the value } \\
\text { The main character of the narrative }\end{array}$ \\
$\begin{array}{l}\text { Subject } \\
\text { Object }\end{array}$ & $\begin{array}{l}\text { Subject } \\
\text { Odjuvant/Hect } \\
\text { Supporter }\end{array}$ & $\begin{array}{l}\text { What the subject (goal) wants to achieve } \\
\text { Encouraging the subjects to achieve their goals } \\
\text { (objects) } \\
\text { Obstructing the subject from achieving his goal }\end{array}$ \\
\hline
\end{tabular}

Table 1. Kind of Actants

Those actants can be illustrated as follows: ${ }^{21}$

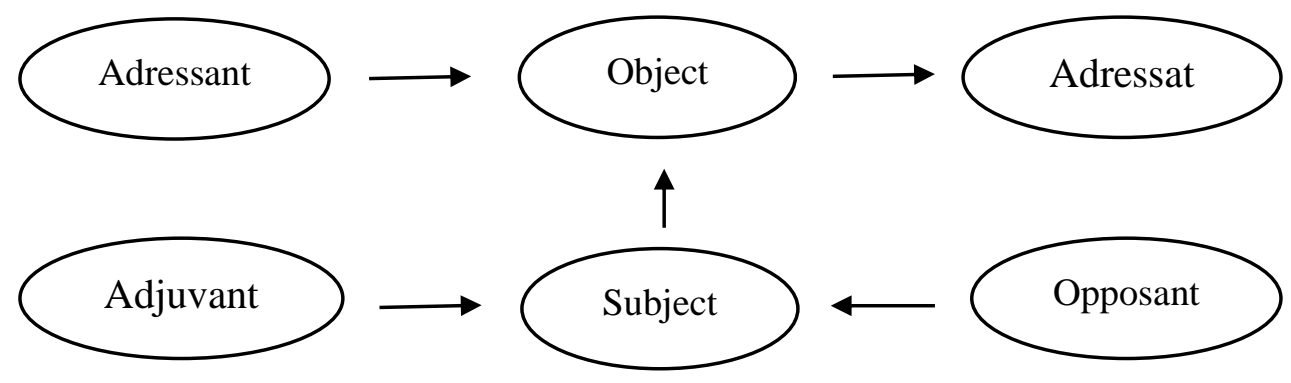

Diagram 1. Actants Illustration

${ }^{19}$ Kukuh Yudha Karnanta. 2015. Struktural (Dan) Semantik: Teropong Strukturalisme dan Aplikasi Teori Naratif A.J. Greimas. Atavisme, Volume 18 (2), page 175.

${ }^{20}$ Nor Istiqomah. Aplikasi Semiotika Naratif A.J. Greimas terhadap Kisah Thalut dalam al-Qur'an. page 81. See Wildan Taufiq. 2016. Semitika untuk Kajian Sastr dan al-Qur'an. Bandung: Yrama Widya, page 107.

${ }^{21}$ Alirdas Julien Greimas. 1971. Struktural Sematik: Methodologiesche Untersuchungen, translated by Auge, Gilon, dkk. New York: Pergamon Press, page 165 
While the inner structure is also known as Greimas Semiotic Square: ${ }^{22}$

\begin{tabular}{ll}
\hline Types of Relation & Elements of Relation \\
\hline Opposite & $\mathrm{S} 1+\mathrm{S} 2$ \\
Opposite & $-\mathrm{S} 2+-\mathrm{S} 1$ \\
Contradiction & $\mathrm{S} 2+-\mathrm{S} 2$ \\
Contradiction & $\mathrm{S} 2+\mathrm{S} 1$ \\
Implication & $-\mathrm{S} 2+\mathrm{S} 1$ \\
Implication & $-\mathrm{S} 1+\mathrm{S} 2$ \\
\hline
\end{tabular}

Table 2. Greimas Semiotic Square

It also can be seen from this picture: ${ }^{23}$

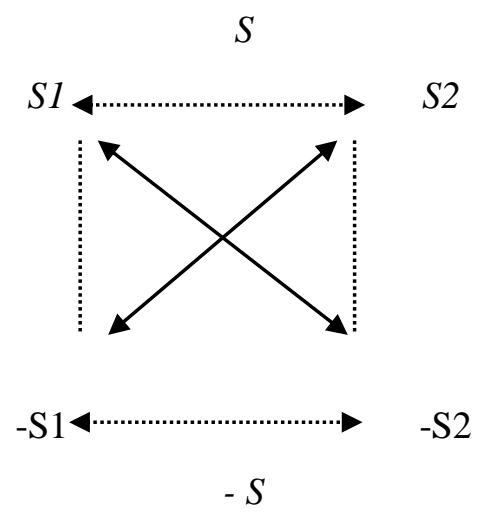

\section{Diagram 2. Greimas Semiotic Square}

Furthermore, there are several steps, as suggested by Nor Istiqomah, that are used in Greimas's narrative semiotics including: ${ }^{24}$

1. providing a general description of the story broken down in certain segments;

2. determining the actants in each segment;

3. creating a functional text structure;

\footnotetext{
hlm. 82 .

${ }^{22}$ Nor Istiqomah, “Aplikasi Semiotika Naratif A.J. Greimas terhadap Kisah Thalut dalam al-Qur'an” Collins, hlm. 49.

${ }^{23}$ Algirdas Julien Greimas, On Meaning Selected Writing in Semiotic Theory, terj. Perron and Frank H.

${ }^{24}$ Nor Istiqomah. Aplikasi Semiotika Naratif A.J. Greimas terhadap Kisah Thalut dalam al-Qur'an, page 82 .
} 
4. determining the relationship between the act so that the main act is found in the entire segment;

5. determining the extrinsic structure of the text;

6. analysing the inner structure of each segment by looking at the formula of it;

7. determining the overall inner structure; and

8. drawing conclusions.

\section{The Application of Greimas's Narrative Theory on the Story of the Garden Owner}

The story about the owner of the garden in the Qur'an is written in surah al-Qalam verses 17-32 (16 Verses). This story, according to the Quraish Shihab, was familiar among the Meccan polytheists when this verse was revealed, namely in the Dharawan area not far from Shan ' a, Yemen. ${ }^{25}$ The names of the characters of the story in this surah al-Qalam are not clearly stated. But, in general, this story tells the rewards that the owner of the garden has suffered due to their miserliness to share the yields of their garden with the poor. At the beginning of the story, Allah made this story as a parable for the people (polytheist) who were given a temptation, where Allah placed (the yields) of the garden as a temptation for their owners. The owners are reluctant, even do not want, that the harvest is distributed to the poor. Because of their action, Allah sent down a torment at night by burning their gardens. When morning came, they went to their gardens to harvest the crops, but they could not because their gardens were already burned. The owner of the garden then realized that it happened because of the sins they had committed. Therefore, they immediately realize, repent, beg for forgiveness of their sins, and ask for better compensation than the previous one.

The story above was explained in more detail in the Qishashul Qur'an, especially about the garden which is inherited from the father. It was explained that the garden in the very fertile area of Dharawan belonged to a Shaykh from Bani Israel who was famous for his piety and generosity. The yield was always distributed to the poor. He carried out this habit until he passed away. Before his death, he told his children to continue distributing the yields of the garden even after he left. ${ }^{26}$ But apparently, the will of the father was not heeded by his

${ }^{25}$ M. Quraish Shihab. 2011. Tafsir Al-Misbah: Pesan, Kesan, dan Keserasian al-Qur'an, vol. XIV. Jakarta: Lentera Hati, page 387.

${ }^{26}$ See more on Muhammad Ahmad Jadul, Muhammad Abu Fadhli Ibrahim, dkk. Buku Induk Kisah AlQur'an, translated by Abdurrahman Assegaf, page 355-360. 
children. From this reality, God gave punishment to the child as the successor to the owner of the garden.

\section{a. Actant 1 in the first segment}

The first actant in the story is found in surah al-Qalam verses 17-18 which is the beginning of the story about the owner of the garden. The theme in the first segment will be "ujian kepada pemilik kebun", as described in the following verse:

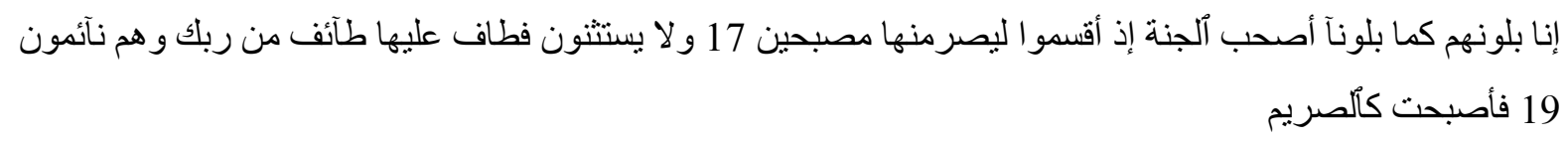

"Indeed, We have tried them as We tried the companions of the garden, when they swore to cut its fruit in the [early] morning. Without making exception. So, there came upon the garden an affliction from your Lord while they were asleep. And it became as though reaped"

Actants in the first segment are as follows:

$\begin{array}{ll}\text { Sender } & : \text { Garden } \\ \text { Receiver } & : \text { Poor people } \\ \text { Subject } & : \text { Garden Owners } \\ \text { Object } & : \text { Garden yields } \\ \text { Helper } & : \text { A strong desire to harvest } \\ \text { Opposant } & : \text { Scorched garden }\end{array}$

Sender in the first segment is the garden. In the story, the garden owners become the subject, who have a strong desire to reap the yields from their garden. The passion of the gardeners in this story is called Helper. Furthermore, a strong desire to have all the yields (harvests) of the garden made them agreed not to share it with the poor, as the opposite of what their father used to do. In this first segment, the poor are called Receivers for the treatment of the garden owners. Due the arrogance and stingy nature of the garden owners, God punished them by burning their gardens at night. The scorch of the garden in this story is deemed as the Opposant.

\section{b. Actant 2 in the second segment}

The second segment of the story about garden owners "Sifat kikir pemilik kebun" is contained in the QS. Al-Qalam verses 210-25:

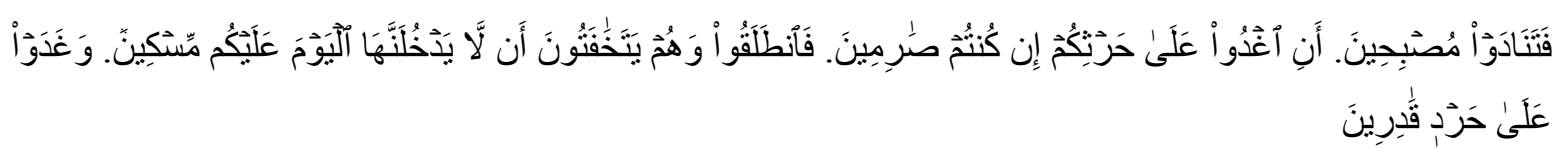


"And they called one another at morning [Saying], "Go early to your crop if you would cut the fruit." So, they set out, while lowering their voices, [Saying], "There will surely not enter it today upon you [any] poor person." And they went early in determination, [assuming themselves] able."

Actants in the second segment are as follows:

Sender : Miser

Receiver : Other garden owners

Subject : The garden owner

Object : Harvesting fruit

Helper : Determination to deter the poor

Opposant : Poor rights

The Sender in the second segment above is the miser inherent in the character of the garden owner. In this story, there is a dialogue among the owners of the gardens. They plan to harvest their yields without the presence of the poor. The owners of the garden are the subject of the second segment of this story. Furthermore, other garden owners are invited and agreed and the plan in this case becomes Receiver. Then the garden owners took an early morning to harvest the fruits from their garden together. Picking fruit becomes the object of story. Their efforts to reap the yields were accompanied by a strong determination to prevent the poor from participating in harvesting their produce. In this context, the above determination is called Helper. They did not realize that every harvest has the right of the poor in it, this is because it has helped them. It is very beloved to Allah that we share with the less fortunate whatever we have.

\section{c. Actant 3 in the third segment}

The third segment in the story of the garden owner with the theme "Repentant Garden Owners" is written in QS. Al-Qalam verses 26-32:

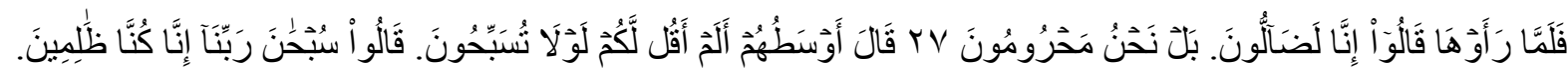

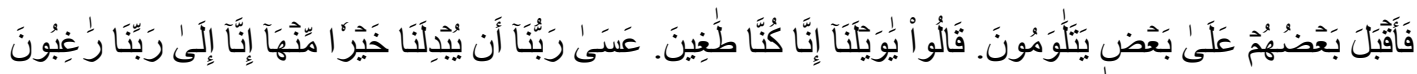

"But when they saw it, they said "Indeed, we are lost, rather than we have been deprived." The most moderate of them said, "Did I not say to you, "Why do you not exalt (Allah)?" They said, "Exalted is our Lord! Indeed, we were wrongdoers." Then they approached one another, blaming each other. They said, "O woe to us, indeed we were transgressors. Perhaps our Lord will substitute for us (one) better than it. Indeed, we are toward our Lord desirous." 
Actants in the third segment above are as follows:

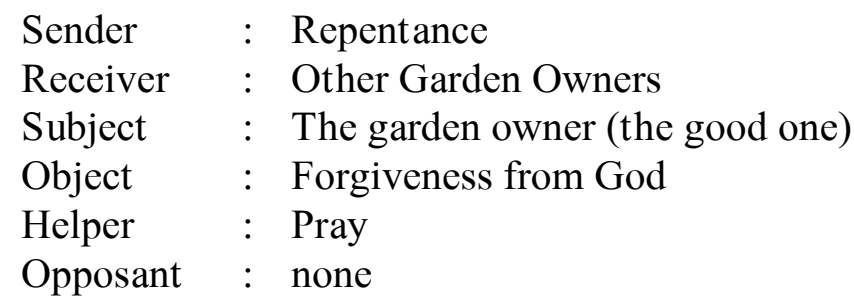

The Sender in this segment is the repentance which begins with the awareness of the garden owner when they witnessed the burned garden. A good garden owner becomes the Subject in this story, he advises his brother who own other gardens. The other garden owners in this story becomes Receivers. All of them felt regretful over their misdeed and they begged for forgiveness from God. In this context, forgiveness from God becomes the Object in this story. To facilitate the confession of sins and forgiveness from God, they prayed "Glory to our Lord, indeed we are wrongdoers" and "Perhaps our Lord will substitute for us with (gardens) that better than it; indeed, we expect forgiveness from our Lord". What they pray for in this story is the Helper. There is no obstacle (Opposant) that they find in in seeking for forgiveness from God.

\section{d. Functional Structure}

The table below shows the actants so that it will be easier to understand about the narratives about the owner of the garden. The functional structure of each act in the story about the owner of the garden is as follows:

\begin{tabular}{|c|c|c|c|}
\hline & Actant 1 & Actant 2 & Actant 3 \\
\hline Sender & Garden & Miser & Repentance \\
\hline Receiver & Poor people & Other garden owners & Other Garden Owners \\
\hline Subject & Garden owners & The garden & $\begin{array}{l}\text { The garden owner (the } \\
\text { good one) }\end{array}$ \\
\hline Object & Garden yields & Har & Forgiveness from God \\
\hline Helper & $\begin{array}{l}\text { A strong desire to } \\
\text { harvest }\end{array}$ & $\begin{array}{l}\text { Determination to deter } \\
\text { the poor }\end{array}$ & Prayer \\
\hline Opposant & Scorched garden & Poor rights & - \\
\hline
\end{tabular}

Table 3. The Functional Structure of Each Act

\section{e. Main Actor}

In finding the main actant in this story, it is necessary to expose the previous actants as a whole. After that, the actants are analysed by looking at how they related one another. The three actants are explained as follows. 
The relationship between actant was found in the actants of sender including gardens, miser, and penance. All three are connected to the storyline where the problem-solving exists, and because of their being miser, God punished them until they repent. In the actant of receiver, the most dominant were the other garden owners, who have bad attitude. The subject in this story is the owner of the garden, who shows the character through the sender they faced. The object in this story is the benefit of the garden which is implied by each of the first, second and third actant. The garden yields and fruit picking refer clearly to the garden, while forgiveness from God refers to the demand for the substitution for their garden (or the better one). The helper of this story is like a wave, which initially only an intention (Actant 1) and then becomes an action (Actant 2), until finally awakened so they pray to God (Actant 3). While the Opposant is the scorched of the gardens and the rights of the poor.

Therefore, the main actant of the story is:

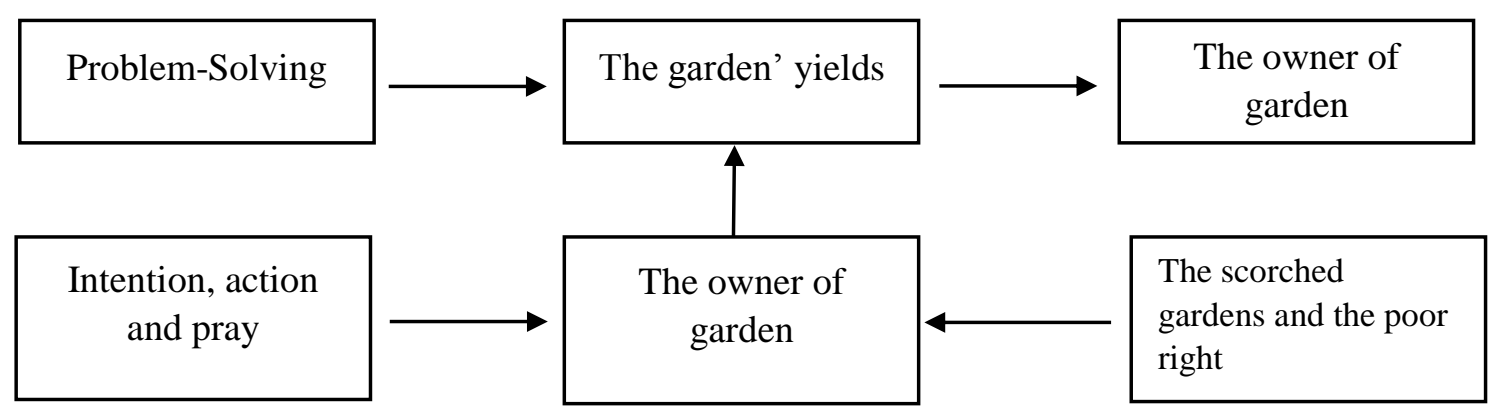

Diagram 3. The Main Actants Illustration

Thus, the extrinsic structure from the story describes the owner of the garden in maintaining the gardens well, and this is in line with the problem-solving (problemssolutions) they face. Their intentions and actions were ended with awareness (prayer) so that they return to the right path However, they saw and witness the scorched of their gardens as well as paying more attention to the rights of the poor people. 


\section{f. Inner Structure}

The inner structure contained in each actant segment as mentioned below:

1. Daydream : disappointment : no daydream : not disappointed

2. Ambition : forget oneself : no ambition : do not forget oneself

3. Repentance : being humble : do not : arrogant repent

The inner structure that can be captured from the text of the Qur'an, especially those that discuss the story about the owner of the garden is how the story illustrates the human weaknesses in their plans (wishful thinking - ambition - repentance). The greater the responsibility they have, the more they realize that they cannot handle everything on their own, and the forgetfulness of others (God and fellow humans) will only harm them.

\section{CONCLUSION}

From the various explanations above, it can be concluded:

1. In general, this story tells of the punishment to the garden owners because they did not want to share or distribute the garden yields to the poor. They are reluctant, even do not want, if the harvest is distributed to the poor. Therefore, Allah punish them by burning (scorching) their gardens at night. Witnessing the condition of the garden, they realized that it happened because of the sins they have committed.

2. In reading the story about the owner of the garden, Greimas's narrative theory was used in describing the character of the garden owner who is stingy but quickly awakened. This story seeks to reveal the problem-solving they encountered. Their intentions and actions ended with awareness (prayer) so that they finally return to the right path. However, they saw and witness the scorched of their gardens as well as paying more attention to the rights of the poor people.

3. Through this story, a message (inner meaning) is implied from God that perhaps what is possessed and proud of is only a test from God, in which He actually commanded to use it wisely. Another message is that human should be aware of their limited power, so they realize that they need help from God as well as from other people. 


\section{REFERENCES}

Al-Khalidy, S. A. (2000). Kisah-kisah al-Qur'an. (S. B. Utomo, Trans.) Jakarta: Gema Insani.

Anggraini, C. D., Maylanny, C., \& Putra, D. S. (2016). Analisis Struktural Naratif Algirdas Greimas pada Artikel Storytelling Project Sunlight PT. Unilever Indonesia pada Bulan November 2014. e-Proceeding of Management, 3, p. 929.

Aziz, H. (2017, Maret). Kontekstualisasi Kemukjizatan Sastrawi al-Qur’an. Islamica, 11(2).

Faridat unnisa, N. (2015). Kisah-Kisah Zu al-Qurnain dalam al-Qur'an. Tesis Fakultas Ushuluddin dan Pemikiran Islam UIN Sunan Kalijaga.

Greimas, A., \& Cortes, J. (1982). Semiotika and Language: An Anlytical Dictionary. (L. Crist, Trans.) Bloomington: Indiana University Press.

Greimas, A., \& Courtes, J. (1971). Methodologiesche Untersuchungen . (G. d. Auge, Trans.) New York: Pergamon Press.

Greimas, A., \& Courtes, J. (1987). On Meaning Selected Writing in Semiotic Theory. (P. a. Collins, Trans.) Canada: University of Minnesota Press.

Halim, A. M. (2007). Kisah Bapak dan Anak dalam al-Qur'an. (A. H.-K. Wardie, Trans.) Jakarta: Gema Insani.

Imron, A. (2010). Kisah Nabi Yusuf A.S. dalam al-Qur'an. Tesis Fakultas Ushuluddin dan Pemikiran Islam UIN Sunan Kalijaga.

Imron, A. (2011). Semiotika Al-Qur'an: Metode dan Aplikasi terhadap Kisah Yusuf. Yogyakarta: Teras.

Istiqomah, N. (2017). Aplikasi Semiotika Naratif A.J. Greimas terhadap Kisah Thalut dalam al-Qur'an. Qof, 1(2).

Jadul, M., Ibrahim, M., \& dkk. (2009). Buku Induk Kisah Al-Qur'an. (A. Assegaf, Trans.) Jakarta: Zaman.

Karnanta, K. Y. (2015). Struktural (Dan) Semantik: Teropong Strukturalisme dan Aplikasi Teori Naratif A.J. Greimas. Atavisme, 18(2).

Muzakki, A. (2007). Kontribusi Semiotika dalam Memahami Bahasa Agama. Malang: UINMalang Press.

Piliang, Y. A. (2003). Hipersemiotika: Tafsir Cultural Studies atas Matinya Makna. Yogyakarta: Jalasuta.

Piliang, Y. A. (2012). Semiotika dan Hipersemiotika: Gaya, Kode, dan Matinya Makna. Bandung: Matahari.

Prasetyo, E. (2012). Kisah-kisah pembebasan dalam al-Qur'an. Yogyakarta: Resist Book.

Shihab, M. Q. (2011). Tafsir Al-Misbah: Pesan, Kesan, dan Keserasian al-Qur'an(Vol. XIV). Jakarta: Lentera Hati. 
The Application of Narrative Theory by Greimas...(Muhammad Alwi HS \& Iin Parninsih)

Shihab, M. Q. (2013). Kaidah Tafsir: Syarat, Ketentuan, dan Aturan yang Patut Anda ketahui dalam Memahami Ayat-Ayat al-Qur'an. Tangerang: Lentera Hati.

Smas, B. (2012). Seri Kisah-kisah dalam al-Qur'an Seri 1. Bandung: Remaja Rosdakarya.

Smas, B. (2012). Seri Kisah-kisah dalam al-Qur'an Seri 2. Bandung: Remaja Rosdakarya.

Taufiq, W. (2016). Semitika untuk Kajian Sastr dan al-Qur'an. Bandung: Yrama Widya. 